УДК 631.11:339.138

DOI: https://doi.org/10.37320/2415-3583/16.9

Єкель Г.В.

кандидат економічних наук, докторант Центральноукраӥнський національний технічний університет ORCID: https://orcid.org/0000-0003-0634-2047

\title{
ЕКОНОМІЧНИЙ МЕХАНІЗМ МАРКЕТИНГУ ВИРОБНИЦТВА ЕКОЛОГОБЕЗПЕЧНОЇ ПРОДУКЦЇ̈
}

У статті представлено економічний механізм маркетингу виробництва екологобезпечної продукції. Упровадження економічного механізму маркетингу виробниитва екологобезпечної продукиії доцільно поводити у кілька етапів: проводяться маркетингові дослідження цільових та міжнародних ринків, здійснюється складання програм та планів маркетингу та налагоджується робота з клієнтами, впроваджується система маркетингу і конверсї̈ продаж, відбувається визначення результату. Останнім етапом є вдосконалення: планування й упровадження рекомендачій. У иій статті ми показуємо, що вдало розроблений та впроваджений економічний механізм маркетингу виробництва екологобезпечної продукиї сприятиме виріменню низки завдань товаровиробника: формування інновачійно-інвестиційної моделі розвитку господарства; займання конкурентної позиції на аграрному ринку.

Ключові слова: система, маркетинг, виробництво, функиіонування підприємств, екологобезпечна продукція, механізм.

Постановка проблеми. Якщо говорити нині про виробництво екологобезпечної продукції, то це «блакитний» ринок, на якому майже відсутня конкуренція, з одного боку, а з іншого - мало хто знайомий із цією продукцією. Питання екологізації у сільському господарстві в Україні тільки набирає обертів. Споживачі знають органічний ринок, однак не завжди 3 кращого боку. Заплямованість і сумнівна «сертифікація», відсутність повного контролю над дотриманням норм під час виробництва даного товару викликають недовіру серед покупців, тому під час виходу на ринок необхідно створити довірчі відносини «продавець - покупець». 
Позиціонування, створення власної ніші на агропромислових ринках, збутова політика та вдосконалення обслуговування та сервісу клієнта виходять сьогодні на перше місце. Запорукою ведення ефективного бізнесу нині виступає не лише наявність ресурсів, креативного мислення у товаровиробника, виготовлення та пропозиція товару, а й створення попиту на продукцію. Усе це можливо зробити за допомогою економічного механізму маркетингу виробництва екологобезпечної продукції.

Умови ведення бізнесу в 2021 р. суттєво змінилися. На перший план виходить здійснення діяльності в ситуації невизначеності. Логістичні схеми набувають модифікації. Товарно-збутова політика формується фактично в кризовому періоді. I тоді нового значення набуває вся система маркетингу. Удало розроблений та адаптований економічний механізм маркетингу виробництва екологобезпечної продукції здатний не лише утримати товаровиробника на плаву, а й збагатити, при цьому забезпечуючи потреби покупця та не знижуючи якість продукції. Він виступатиме частиною загального механізму взаємодії з ринком та господарського механізму. Саме він здатний урегулювати стосунки клієнта та підприємця і зробити бізнес прибутковим за будь-яких умов.

Аналіз останніх досліджень і публікацій. Вагомий внесок у формування сучасної концепції соціальноетичного маркетингу здійснили закордонні дослідники, серед яких - А. Діб, Ф. Котлер, Г. Амстронг, В. Вонг, Дж. Боуэн, Дж. Мейкенз, А. Асаул, Х. Гастингс та ін. Водночас не слід залишати без уваги праці таких вітчизняних учених О. Прокопенко, В. Кардаша, С. Ілляшенка, А. Войчака, В. Герасимчука, О. Ульянченка, В. Писаренка, Т. Процюк, Л. Слюсаревої, О. Бальцького. Серед українських науковців вивчення маркетингу проводили: А. Войчак, В. Герасимчук, Ю. Дайновський, В. Кардаш, Н. Куденко, Т. Лук'янець, I. Лилик, М. Окландер, А. Павленко, В. Пилипчук, С. Скибінський, А. Старостіна, О. Стецович, В. Тамберг, Н. Буга, О. Ковінько, В. Гуцуляк та ін. Сьогодні екологобезпечним технологіям присвячено багато наукових праць вітчизняних учених, зокрема: В. Артиша, В. Вовк, Т. Галушкіної, В. Грекова, О. Ковальової, В. Сайко, О. Скидан, А. Ендрес, І. Кобушко, Н. Зіновчук, І. Хорішко, О. Ходаківської та ін.

Існує чимало підходів до визначення та формування механізму маркетингу. Сказати, який із них вірний, досить складно. Однак досліджень, які розглядають маркетинг із погляду покупця та здійснення діяльності в нових умовах ведення бізнесу, нині недостатньо.

Мета статті полягає у розробленні економічного механізму маркетингу виробництва екологобезпечної продукції.

Виклад основного матеріалу. Маркетинг дає відповідь на те, як конкурувати на основі інших, нецінових принципів. Через надлишок виробничих потужностей це сьогодні важливо як ніколи. Відділ маркетингу відповідає в компанії за виробництво клієнтів. На думку Ф. Котлера, процвітання та успіх компанії визначаються маркетинговими ідеями та пропозиціями, які реалізують ці ідеї [7, с. 93].

Маркетинг - стратегія, яку ви використовуєте для того, щоб ваш ідеальний цільовий ринок про вас дізна- вся, щоб ви йому сподобалися і він зміг вам довіряти настільки, щоб стати вашим клієнтом [2, с. 122].

Маркетинг - це організаційна функція і сукупність процесів створення, просування та надання цінностей для покупців, а також управління відносинами 3 ними 3 вигодою для організації та іiі власників [8, с. 25].

Під час розроблення економічного механізму маркетингу виробництва екологобезпечної продукції також варто розглянути питання екологічного маркетингу.

Екологічний маркетинг (англ. green marketing) специфічний вид маркетингу, який передбачає орієнтацію усієї діяльності підприємства (розроблення продукції, іiі виробництва, пакування, транспортування, реалізації, просування, переробки та утилізації) на формування та задоволення екологічно орієнтованого попиту з метою отримання прибутку та збереження довкілля і здоров'я людей [6, с. 218].

Alfred Endres визначає екологічний маркетинг як особливий вид людської діяльності, спрямований на задоволення нестачі і потреб за допомогою обміну, але який не зачіпає екологічної рівноваги навколишнього природного середовища і не впливає на стан здоров'я суспільства. Основні функції екологічного маркетингу: вивчення попиту на екологічно чисту продукцію, ціноутворення; реклама і стимулювання; планування екологічно чистого асортименту, збуту i торговельних операцій; діяльність, яка пов'язана зі зберіганням i вибором екологічно чистого товароруху, організацією екологічно безпечного обслуговування споживачів [3, c. 57].

На нашу думку, екологічний маркетинг є також складовою частиною механізму взаємодії з ринком. Серед інших елементів можна виділити: позиціонування, частку ринку, ціну, асортимент і номенклатуру продукції, створення клієнтської бази та попиту на продукцію, рівень та термін обслуговування.

Гуцуляк пропонує серед структурних складників маркетингового механізму забезпечення конкурентоспроможності сільськогосподарського підприємства використовувати такі: конкурентоспроможність продукції даного підприємства на ринку, логістику товаропросування, маркетингові комунікації, сегментування ринку, фінансове забезпечення діяльності, інвестиційно-інноваційне забезпечення, систему управління, диференціацію продукції [5, с. 145].

Буга i Ковінько пропонують виділити у складі маркетингового механізму товарну політику, ціноутворення, методи збуту, маркетингові комунікації $[1$, c. 252].

О.Ю. Стецович уважає, що дослідження функціонування аграрних підприємств із погляду їхньої маркетингової діяльності повинно здійснюватися за такими напрямами:

- аналіз ресурсного потенціалу;

- ефективність використання ресурсів;

- оцінка фінансового стану [11, с. 717].

На нашу думку, розроблення економічного механізму маркетингу виробництва екологобезпечної продукції складатиметься 3 кількох основних етапів (рис. 1). Розглянемо їх детальніше. Перший етап - діагностика, відбуваються маркетингові дослідження цільових та міжнародних ринків та здійснюється формування мети i завдань механізму маркетингу для 


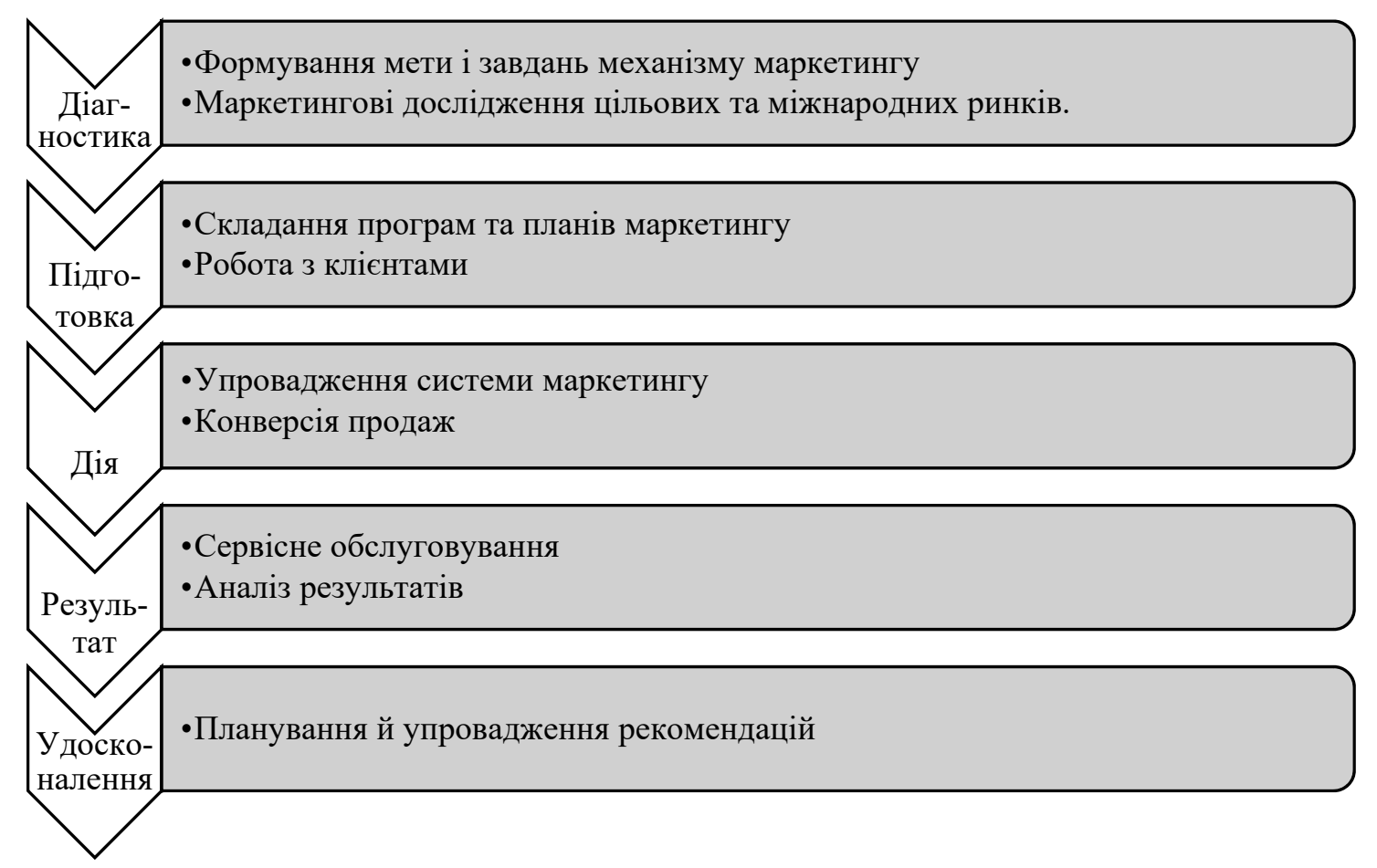

Рисунок 1 - Етапи економічного механізму маркетингу виробництва екологобезпечної продукції

конкретного товаровиробника. На даному етапі відбувається позиціонування фірми на міжнародних і галузевих ринках країни.

Велике значення має формування бренду компанії. Як зазначає Гастингс, бізнес-процеси та технології ключ до успішної побудови бренду. Створення цінності бренду на локальному ринку може згенерувати новий потік доходів на глобальному ринку, ще більше збільшити вартість бренду [4, с. 130].

За допомогою низки інструментів проводиться виявлення попиту на існуючі та нові продукти, вивчення якості виготовлених товарів та оцінка їх відповідності міжнародним стандартам якості. Фактично на даному етапі відбувається оцінка маркетингового потенціалу.

Маркетинговий потенціал визначають як «сукупність внутрішніх можливостей та зовнішніх шансів задовольняти потреби споживачів та отримувати на цій основі максимальні економічні вигоди» [10, с. 221].

Використовуються такі основні інструменти: STEPаналіз, SWOT-аналіз, SPACE-аналіз, GAP-аналіз, PIMS-аналіз, методи прогнозування, метод вивчення профілю об'єкта, портфельний аналіз. За допомогою них відбувається визначення ємності, структури, режиму функціонування, типу ринку, бар'єрів виходу на ринок тощо.

На даному етапі доцільно застосувати екологічний контроль. Попереджувальний екологічний контроль спрямований на визначення обгрунтованості та правильності:

- вибору майданчика для будівництва та розміщення тваринницьких і птахівницьких підприємств;

- дотримання природоохоронних заходів, які приймаються в проєктно-технологічних рішеннях, техно- логії будівництва очисних споруд і систем підготовки органічних добрив до використання 3 урахуванням усіх умов;

- планування у проєкті й натурі достатньої кількості сільськогосподарських угідь та їхньої придатності для утилізації отримуваних [12, с. 132].

Закінчується даний етап вибором цільового ринку, формуванням ніші, розробленням стратегії.

Наступний етап - підготовка: відбувається складання програм та планів маркетингу, робота з образом покупця.

Етап «дія» включає вихід на ринок, а саме впровадження розробленої системи маркетингу в життя. Визначаються канали розподілу товарів. Тут і відбувається створення повідомлення, залучення потенційних клієнтів за допомогою рекламних носіїв. Заключним пунктом є конверсія продаж.

На наступному етапі відбувається визначення результату: аналізується прибуток та впроваджується сервісне обслуговування.

Стосовно клієнтів виконуються два основних завдання: забезпечення найвищої якості товару та підвищення довірчої цінності.

Аналіз продукту відбувається за такими напрямами:

- аналіз життєвого циклу продукту і стратегії маркетингу;

- аналіз життєвого циклу продукту і фінансової ситуації;

- аналіз життєвого циклу продукту і конкуренції;

- аналіз життєвого циклу продукту і факторів продуктивності;

- аналіз впливу зацікавлених сторін [9, с. 15].

Сервісне обслуговування має велике значення в умовах невизначеності. Клієнт завжди має залишатися 
задоволеним та, незважаючи на систему обмежень, отримувати свій товар чи послугу у визначений час. Тому гнучкість буде основним принципом під час розроблення системи сервісу.

Останнім етапом є вдосконалення планування й упровадження рекомендацій. Тут за допомогою механізму маркетингу вирішуються такі завдання:

- отримання оперативної інформації про нововведення і впровадження інновації у виробничу й організаційну діяльність;

- своєчасне виявлення та нейтралізація ризиків, пов'язаних із маркетинговою діяльністю;

- постійний моніторинг ринкового середовища.

Висновки. Удало розроблений та впроваджений економічний механізм маркетингу виробництва екологобезпечної продукції сприятиме вирішенню низки завдань товаровиробника:
- формуванню інноваційно-інвестиційної моделі розвитку господарства;

- займанню конкурентної позиції на аграрному ринку;

- поглибленню міжгалузевої та міжнародної форм інтеграцій;

- налагодженню ефективних стосунків «споживач - постачальник»;

- посиленню каналів реалізації продукції.

Основою правильно розробленої та вдало функціонуючої системи маркетингу є люди. Це виконавці, з одного боку, та споживачі - 3 іншого, тому людський фактор визначальний для маркетингу.

Велике значення для ефективної роботи економічного механізму маркетингу виробництва екологобезпечної продукції має система логістичних сполучень, особливо в нинішніх умовах, тому, наші подальші дослідження проводитимуться саме у цьому напрямі.

\section{Список використаних джерел:}

1. Буга Н.Ю., Ковінько О.М., Шамалюк Д. Формування маркетингового механізму розвитку підприємства. Економіка та управління підприємствами. 2017. № 20. С. 250-254.

2. Діб А. Маркетинговий план на одну сторінку / пер. з англ. Харків : Віват, 2020. 288 с.

3. Эндрэс А. Экономика окружающей среды: введение / пер. с нем. Київ : Либідь, 1995. 168 с.

4. Гастінгс Х., Саперштайн Д. Практичні шляхи поліпшення маркетингу для зростання вашого бізнесу. Як нове розуміння потреб клієнта та інновації призводять до зростання цінності бренду і бізнесу в цілому / пер. 3 англ. Дніпропетровськ : Баланс Бізнес Букс, 2012. 272 с.

5. Гуцуляк В.Р. Маркетинговий механізм як інструмент підвищення конкурентоспроможності сільськогосподарських підприємств на ринку. Соціально-економічні проблеми сучасного періоду Украйни. 2016. № 1(117). С. 144-147.

6. Кобушко И.Н. Финансово-экономический механизм экологизации общественного производства. Механізм регулювання економіки, економіка природокористування, економіка підприємства та організаиія виробництва. 2004. № 4. С. $217-227$.

7. Котлер Ф. Маркетинг от А до Я: 80 концепций, которые должен знать каждый менеджер / пер. с англ. Київ : Альпіна Паблішер, 2020. 242 с.

8. Котлер Ф., Келлер К. Маркетинговий менеджмент. Київ : Хімджест, 2008. 720 с.

9. Редченко К.І. Стратегічний аналіз у бізнесі : навчальний посібник ; 2-е вид., доп. Львів : Новий світ - 2000, 2003.272 с.

10. Ришар Ж. Аудит и анализ хозяйственной деятельности предприятия / пер. с франц. Москва : Аудит, ЮНИТИ, 1997. 375 с.

11. Стецович О.Ю. Маркетинг в системі АПК. Вісник Львівського державного аграрного університету. Економіка АПК. 2006. № 13. С. 716-718.

12. Зіновчук Н.В. Екологічна політика в АПК: економічний аспект : монографія. Львів : Львівський держ. аграр. ун-т, ННВК «АТБ», 2007. 394 c.

\section{References:}

1. Buha N.Y., Kovinko O.M., Shamaliuk D. (2017) Formuvannia marketynhovoho mekhanizmu rozvytku pidpryiemstva [The formation of a marketing mechanismof enterprise development]. Ekonomika ta upravlinnia pidpryiemstvamy, no. (20), pp. $250-254$.

2. Dib A. (2020) Marketynhovyi plan na odnu storinku [The 1-page marketing plan: get new customers, make more money, and stand out from the crowd]. Kharkiv: Vivat. (in Ukrainian)

3. Endres A. (1995) Ekonomika okruzhaiushchei sredy [Environmental Economics]. Kyiv: Lybid. (in Russian)

4. Hastings H., Saperstein J. (2012) Praktychni shliakhy polipshennia marketynhu dlia zrostannia vashoho biznesu. Yak nove rozuminnia potreb kliienta ta innovatsii pryzvodiat do zrostannia tsinnosti brendu i biznesu v tsilomu [Improve your marketing to grow your business : insights and innovation that drive business and brand growth]. Dnipropetrovsk: Balance Business Books. (in Ukrainian)

5. Hutsuliak V.R. (2016) Marketynhovyi mekhanizm yak instrument pidvyshchennia konkurentospromozhnosti silskohospodarskykh pidpryiemstv na rynku [Marketing mechanism as a tool to improve the competitiveness of agricultural enterprises in the market]. Socioeconomic problems of the modern period of Ukraine, no. 117(1), pp. 144-147.

6. Kobushko I.N. (2004) Finansovo-ekonomicheskii mekhanizm ekologizatcii obshchestvennogo proizvodstva [Financial and economic mechanism of the greening of social production]. Mechanism of Economic Regulation, no. 4, pp. 217-227.

7. Kotler P. (2020) Marketynh ot A do Ya: 80 kontseptsyi, kotorye dolzhen znat kazhdyi menedzher [Marketing insights from A to Z: 80 Concepts Every Manager Needs To Know]. Kyiv: Alpina Pablisher. (in Russian)

8. Kotler P., Keller K.L. (2008) Marketynhovyi menedzhment [Marketing management]. Kyiv: Khimdzhest. (in Ukrainian)

9. Redchenko K.I. (2003) Stratehichnyi analiz u biznesi [Strategic analysis in business]. Lviv: Novyi svit-2000. (in Ukrainian)

10. Richard J. (1997) Audit i analiz khoziaistvennoi deiatelnosti predpriiatiia [Audit and analysis of economic activities of the enterprise]. Moscow: Audit, IuNITI. (in Russian)

11. Stetsovych O.Y. (2006) Marketynh v systemi APK [Marketing in the agro-industrial complex]. Journal of Lviv National Agrarian University. Economics of AIC, no. 13, pp. 716-718.

12. Zinovchuk N.V. (2007) Ekolohichna polityka v APK: ekonomichnyi aspekt [Ecological policy in agro-industrial complex: economic aspect]. Lviv: Lvivskyi derzh. ahrar. un-t, NNVK «ATB». (in Ukrainian) 
Yekel Hanna

Central Ukrainian National Technical University

\section{ECONOMIC MECHANISM OF MARKETING OF PRODUCTION OF ENVIRONMENTALLY SAFE PRODUCTS}

The article presents the economic mechanism of marketing the production of environmentally safe products. The author proposes a conceptual approach to its formation, the main components are given. Many papers have found that marketing is an organizational function and a set of creation processes, that it answers how to compete based on other, non-price principles, that it is a strategy that you use to make your ideal target market know about you, to he liked you and he was able to trust you enough to become your customer. The purpose of the article was to develop an economic mechanism for marketing the production of environmentally friendly products. It was obtained that the introduction of an economic mechanism for marketing the production of environmentally friendly products should be carried out in several stages. On the first-there is a formation of the purpose and tasks of the marketing mechanism, marketing researches of target and international markets are carried out. On the second - the manufacturer draws up marketing programs and plans and establishes work with customers. The next step is to implement a marketing system and conversion sales. Then the result is determined: the profit is analyzed and service is implemented. The last stage is improvement: planning and implementation of recommendations. Here, with the help of the marketing mechanism, the following tasks are solved: obtaining operational information about innovations and implementing innovations in production and organizational activity; timely detection and neutralization of associated risks with marketing activities; constant monitoring of the market environment. We show that the successfully developed and implemented economic mechanism of marketing the production of environmentally friendly products will help solve a number of problems of the producer: the formation of innovation and investment model of economic development; taking a competitive position in the agricultural market; deepening intersectoral and international forms of integration; establishing effective consumer-supplier relations; strengthening product sales channels.

Key words: system, marketing, production, operation of enterprises, environmentally friendly products.

JEL classification: Q01, Q13 